\title{
TOTAL QUALITY MANAGEMENT (TQM) PRACTICES AND SCHOOL CLIMATE AMONGST HIGH, AVERAGE AND LOW PERFORMANCE SECONDARY SCHOOLS
}

\author{
Siti Noor Ismail \\ School of Education and Modern Languages \\ Universiti Utara Malaysia \\ siti.noor@uum.edu.my
}

\begin{abstract}
Purpose - This study attempted to determine whether the dimensions of TQM practices are predictors of school climate. It aimed to identify the level of TQM practices and school climate in three different categories of schools, namely high, average and low performance schools. The study also sought to examine which dimensions of TQM practices contributed the most to school climate.
\end{abstract}

Methodology - A survey was administered to 691 teachers from 24 secondary schools to obtain information on TQM practices and school climate. Descriptive statistics was used to examine the level of TQM and school climate and inferential statistics (correlation coefficient and multiple regression) was used to examine relationships between the variables.

Findings - There were significant differences between the levels of TQM practices in the three different categories of schools. High performance schools showed a higher level of TQM practice and school climate, followed by average performance schools and low performance schools. There was a significant positive relationship between the variables on the level of TQM practices and school climate. TQM was a predictor of school climate contributing to 40 percent of the variance towards school climate. For the dimension of TQM practices, staff involvement, commitment of the top management and continuous improvement were the main predictors of school climate. 
Significance - The findings contribute significantly to knowledge by proposing the Excellent School Model which can guide teachers and school administrators in implementing quality management in education.

Keywords: Total quality management, school climate, high, average and low performance schools.

\section{INTRODUCTION}

Quality in education is highly needed in the globalization era as it is believed that a quality education system can produce a workforce with superior personal characteristics, such as being innovative, productive, skillful, competitive, resilient and creative (Mohamad, 2002). In its National Education Blueprint (NEB) (2006-2010), and further enhanced in the National Key Result Areas (NKRAs), Malaysia aspires to develop its human capital by giving attention to, among others, the value system, disciplinary aspects, character, morals and resilience of the students, so as to produce human capital that is competent, innovative, creative and marketable. In this regard, the government has taken various measures to improve the quality of public service management, such as by organizing training on quality management, conducting seminars and workshops and publishing handbooks as guides, for example, the "Total Quality Management (TQM) for the Public Service” (PADC, 1992 ) Handbook.

Quality in education is based on quality of teaching, quality of teachers and quality management. Quality management does not happen overnight. It is achieved through effective management strategies in an organization. TQM is a management philosophy proposed by quality gurus like Deming, Juran, Feigenbaum and Ishikawa. TQM concepts were first introduced in the 1920s, for quality control in factories in the United States. Since then, this concept has been well received among corporate managers in Japan and has been applied in many organizations (Lim \& Tang, 2001). Generally, this study aims to identify the extent of the implementation of TQM practices in schools and its relationship with school climate, as well as the dimensions of TQM which contribute to school climate. 


\section{PROBLEM STATEMENT}

Related studies on TQM have shown that TQM has strong roots in the industry and has contributed to the success of the organizations (Noorliza Karia \& Muhammad Hasmi, 2006; Prajogo \& Sohal, 2002; Prabhu, Alex, Yarrow \& Mitchell, 2000; Anderson \& Sohal, 1999). In addition, other studies have suggested that the implementation of TQM can enhance the performance of educational organizations (Brigham, 1993; Susan, 1995; Koch \& Fisher, 1998; Peat, Taylor \& Franklin, 2005; Sitalakshmi, 2007).

The Malaysian Government has issued the Civil Service Circular No. 1/1992: Guide to Total Quality Management (TQM) for Public Service, and has conducted extensive training for government agencies to enable them, including education agencies, to adopt TQM; however the question is to what extent have the schools adopted this circular's directivs successfully? If all schools have adopted this circular, then why are there high performance, average and low performance schools? Related theories on TQM demonstrate that schools which have adopted TQM have better performance than schools which have not. Studies have also found that when TQM is implemented, the school's performance increases significantly (Lim Kong Teong \& Tang Swee Mei, 2001; Toremen \& Karakus, 2009). Thus, another question arises, i.e., what is the status of TQM practices in Malaysian schools?

Even though many studies have put forth the idea that TQM practices can create a good climate for the organization, only a few studies (Lam, Gary, \& Chin 2008; Kumar \& Sankaran, 2007; Tan, Wong, Mehta, \& Khoo, 2003, Paul, 1998; Farmakis, 1995, Marshall, Pritchard, \& Gunderson, 2004; Kunnanatt, 2007; Toremen $\&$ Karakus, 2009) have tested this proposition. Further, findings are inconsistent on whether the TQM practices change the climate of the organizations or the climate itself determines the success of TQM implementation (Prajogo \& Sohal, 2002). Disagreement creates impetus for researchers to study the impact of TQM and its relationship with the school climate amongst high, average and low performance schools. 


\section{LITERATURE REVIEW}

TQM is a concept that focuses on the overall total management of the organization. Its objective is to deliver quality products or services to customers (Daft \& Becker, 1997). TQM practices create productive organizations and a high-performance work culture (PADC, 1992; Noorliza Karia \& Muhammad Hasmi, 2006; Prajogo \& Mc Dermott, 2005). Although TQM has strong roots in the industry, it also has a strong influence and impact on educational organizations (Sitalakshmi, 2007). Many researchers (Susan, 1995, Koch \& Fisher, 1998; Peat, Taylor \& Franklin, 2005) consider that TQM practices can effectively contribute to the improvement of education quality, especially in curriculum development.

In recent years, educational institutions have shown interest and commitment to the implementation of TQM (Lim Kong Teong \& Tang Swee Mei, 2001). Several studies have found that educational organizations, including schools which have adopted TQM, have shown high performance and satisfaction amongst internal and external customers and the stakeholders (Lim Kong Teong, 2003; Toremen \& Karakus, 2009). If it is true, the Malaysian schools that have adopted TQM practices as directed by the Ministry through the PADC will have the same phenomena as mentioned above. In addition, the schools involved will also have positive climate and quality work culture because TQM has a significantly positive impact on school climate. Some studies have reviewed the influence of TQM on the climate of the organization, including schools (Lam et al., 2008; Marshall et al., 2004; Tan et al., 2003) and have indicated a strong relationship between TQM and school climate. School climate has become one of the variables that determines the efficiency and effectiveness of schools (Prajogo \& McDermott, 2005). It has been claimed that high-performing schools often have a healthier climate (Hoy \& Miskel, 1996).

In addition, other researchers have also highlighted several features of effective school climate. According to Lindahl (2009), positive school climate has significant influence on the success of a school. Studies by Carter (2000), Klinger (2000), Lezotte (2001) and Pashiardis (2000) have found that good quality climate determines the success of the school. Finally, Paul (1998) concludes that positive school climate perhaps is the most important expression of the success of TQM implementation in schools. 
In studying school climate, Johnson and Stevens (2007) used five (5) key dimensions of school climate: collaboration, student relations, school resources, decision-making and teaching innovation. The researchers developed the theoretical framework of the study using this school climate model and the previous studies (Lam et al., 2008; Kumar \& Sankaran, 2007; Tan et al., 2003; Prajogo \& McDermott, 2005).

Based on TQM theories, models (Dahlgaard \& Kristensen, 1995) and previous literature, elements or dimensions for TQM and school climate, have been identified as variables. According to Susan (1995); Koch and Fisher (1998); and Sitalakshmi (2007), TQM contributes to the formation of educational aspects of teamwork, leadership and the continuous improvement in education. Although there are many dimensions of TQM, the most important dimensions used by Ahire, Golhar and Waller (1996, 1999); Anderson and Sohal (1999); Prabhu, et al. (2000); Zhang, Waszine, \& Wijngaard (2000); Prajogo \& Sohal (2002); Baidoun (2003); Prajogo \& Mc Dermott (2005); Noorliza and Muhammad Hasmi (2006); Ngware, Wamukuru \& Odebero (2006); Keng Boon Ooi, Nooh \& Veeri Arumugam (2007); and Das et al. (2008) are: (i) Leadership/Top management commitment; (ii) Continuous improvement; (iii) Customer focus; (iv) Staff involvement; and (v) Training and education.

\section{OBJECTIVES, OF THE STUDY}

This study aims to identify the level of TQM practices in schools and its relationship with the school climate. In addition, the study also examines the dimensions of TQM which contribute the most to the school climate. More specifically the study seeks to investigate:

(a) the level of TQM practices in high, average and low performance schools;

(b) the level of school climate in high, average and low performance schools;

(c) the different levels of TQM practices and school climate among high, average and low performance schools;

(d) the relationship between the dimensions of TQM practices and school climate; and

(e) whether or not TQM can be a predictor of school climate. 
Based on the research objectives, this study seeks to answer the following research questions: -

RQ1 : What is the level of TQM practices in high, average and low performance schools?

RQ2: What is the level of school climate in high, average and low performance schools?

RQ3 : Is there any significant difference in the level of TQM practices and school climate between high, average and low performance schools?

RQ4 : Is there any significant relationship between the dimensions of TQM practices and school climate?

RQ5 : Is there any dimension of TQM which is a significant predictor of school climate?

Based on a detailed study of the objectives and research questions above, the null hypothesis was designed to be tested at the 0.05 significance level:

Ha 1: There is a significant difference in the level of TQM practices in high, average and low performance schools.

Ha 2: There is a significant difference in the level of school climate of high, average and low performance schools.

Ha 3 : There is a significant relationship between the level of TQM practices and school climate.

Ha 4: The dimension of TQM is a predictor of school climate.

\section{METHODOLOGY}

\section{The Survey Questionnaire}

This study is a quantitative study using questionnaires. The questionnaire consists of three (3) parts. Part A is on the background of the respondents; Part B contains items on the level of TQM practices (27 items with a 5-point Likert scale); and Part $\mathrm{C}$ is the items of school climate (21 items with a 5-point Likert scale). The questionnaire for TQM practices consisted of five different constructs: top management commitment; continuous improvements; customer focus; staff involvement; and training and education (Zhang et al., Das et al., Ahire et al., Ngware et al., \& 
Anthony et al.). Further, there are five (5) constructs for the school climate: collaboration; student relations; school resources; decisionmaking; and teaching innovation (Johnson \& Stevens, 2007). Reliability of the instruments developed were tested and the alpha value was found to be above 0.70 .

\section{Participants And Procedures}

A total of 691 teachers from 24 schools were randomly choosen to participate in this study. The sample size was based on Krejcie and Morgan's (1970) sample size determination. According to Creswell (2008), the population of the study means a group of individuals who represent the same criteria with the aims of the study. On the other hand, sample is a subgroup of a target population and the findings on a sample represent the entire population. The survey was conducted on three different categories of secondary schools, namely High Performance Schools (HPS), Average Performance Schools (APS) and Low Performance Schools (LPS) in the state of Kelantan, Malaysia.

Descriptive analysis was used to identify the level of TQM practices and ANOVA analysis was used to examine the differences between the level of TQM practices and the level of school climate in these three categories of schools. Pearson correlation was used to examine the relationship between the two variables of TQM practices and school climate. Finally, multiple regression analysis was used to identify the TQM dimensions that contribute the most to the school climate.

\section{RESULTS AND DISCUSSION}

\section{The Level of TQM Practices in High, Average and Low Performance Schools}

To determine whether there are differences in the level of TQM practices among high, average and low performance schools, oneway ANOVA test was used. Based on one-way ANOVA analysis, the mean for the level of TQM practices in HPS was higher than the level of TQM practices in average and low performance schools. The mean value was 4.50 and the standard deviation was 0.64 compared 
to the level of practices in APS $(\mathrm{M}=4.43, \mathrm{SD}=0.73)$ and LPS (M $=4.09, \mathrm{SD}=0.72$ ). Based on the results of one-way ANOVA test as shown in Table 1, the results show that there are significantly different levels of TQM practices among the three categories of high, average and low performance schools, with values of $F(2,684)$ $=19.48, \mathrm{p}<0.05$.

Table 1

One Way ANOVA Test for the Level of TQM Practices in High, Average and Low Performance Schools

\begin{tabular}{lcccc}
\hline Variation source & $\begin{array}{c}\text { Total } \\
\text { Square }\end{array}$ & $\begin{array}{c}\text { Degrees of } \\
\text { Freedom }\end{array}$ & $\begin{array}{c}\text { Mean } \\
\text { Squared }\end{array}$ & F value \\
\hline Between groups & 19.42 & 2 & 9709 & $19.48^{* *}$ \\
Within group & 340.92 & 684 & .50 & \\
Total & 360.33 & 686 & & \\
** $\mathrm{p}<0.01$ & & &
\end{tabular}

The researchers used descriptive analysis to obtain overall mean values for each domain of TQM practices. Mean value of this comparison was made with the interpretation of the means to determine high or low levels of TQM practices by categories of schools as indicated in Table 2 .

Table 2

Mean TQM practices by Category of School

\begin{tabular}{lccc}
\hline TQM dimensions & Mean HPS & Mean APS & Mean LPS \\
\hline Top Management Commitment & 4.694 .69 & 4.664 .66 & 4.524 .52 \\
Customer Focus & 3.983 .98 & 4.014 .01 & 3.503 .50 \\
Training and Education & 4.434 .43 & 4.384 .38 & 4.124 .12 \\
The involvement of all staff & 5.065 .06 & 4.964 .96 & 4.614 .61 \\
Continuous Improvement & 4.324 .32 & 4.164 .16 & 3.773 .77 \\
Overall & 4.494 .49 & 4.434 .43 & 4.094 .09 \\
\hline
\end{tabular}

Findings in Table 2 indicate that the level of TQM practices in HPS as a whole is high, with the mean value of 4.49. APS also show high level of practice with the mean value of 4.43 , which is lower than the level of TQM practices in HPS. Next, the findings of the LPS show the mean value is fairly high with the overall mean value of 4.09 . It 
is the lowest compared to the level of practices in the HPS and APS. It can be concluded that the level of TQM practices in HPS is the highest compared to the average and the low performance schools; while the level of TQM practices in APS is much higher than the level of TQM practices in LPS.

\section{Levels of Climate in High, Average and Low Performance Schools}

Based on one-way ANOVA test, the results show that the level of climate in HPS is higher than the level of school climate in the average and low performance schools, where the mean is 4.40 with a standard deviation of 0.54 against the climate stage for APS $(\mathrm{M}=$ $4.26, \mathrm{SD}=0.50)$ and LPS $(\mathrm{M}=4.08, \mathrm{SD}=0.47)$. Based on one-way ANOVA test, the results show that there is a significant difference for the level of climate variables between the three categories of high, average and low performance schools, with the value of $\mathrm{F}$ $(2,682)=20.88, \mathrm{p}<0.05$, as shown in Table 3 .

\section{Table 3}

One Way ANOVA Test for the Level of School Climate Differences between High, Average and Low Performance Schools

\begin{tabular}{lcccc}
\hline Variation source & $\begin{array}{c}\text { Total } \\
\text { Square }\end{array}$ & $\begin{array}{c}\text { Degrees } \\
\text { of Freedom }\end{array}$ & $\begin{array}{c}\text { Mean } \\
\text { Squared }\end{array}$ & F value \\
\hline Between groups & 10.34 & 2 & 5.17 & $20.88^{* * *}$ \\
Within group & 168.78 & 682 & .25 & \\
Total & 179.12 & 684 & & \\
\hline
\end{tabular}

$* * \mathrm{p}<0.01$

The mean value in the descriptive analysis was used in order to classify the level of school climate, as shown in Table 4.

Table 4

School Climate by School Category

\begin{tabular}{lccc}
\hline School Climate Dimensions & Mean HPS & Mean APS & Mean LPS \\
\hline Collaborative & 4.56 & 4.53 & 4.51 \\
Student Relations & 4.85 & 4.60 & 4.00 \\
School Resources & 4.19 & 3.95 & 3.90 \\
\hline
\end{tabular}




\begin{tabular}{lccc}
\hline School Climate Dimensions & Mean HPS & Mean APS & Mean LPS \\
\hline Decision-Making & 3.87 & 3.75 & 3.72 \\
Teaching Innovation & 4.56 & 4.51 & 4.29 \\
Overall & 4.41 & 4.27 & 4.08 \\
\hline
\end{tabular}

The findings indicate that the level of school climate in HPS is high with mean value of 4.41 , while the overall mean for the school climate in the APS is quite high, with the mean value of 4.27 and the mean for the level of school climate in LPS is quite high with the mean value of 4.08. The level of school climate in HPS is higher than the school climate in APS, while the school climate in APS is even higher than the school climate in LPS.

\section{The Relationship between TQM Practices and School Climate}

Pearson correlation analysis was used to identify the relationship between the two variables, TQM practices and school climate. Analysis shows positive relationship between both variables with the value of $r=0.63(p<0.01)$, as shown in Table 5. It shows that there is a moderate positive relationship between the two variables and this assumption is very significant because the value of $p$ is less than 0.01. The relationship between the dimensions of TQM practices with the school climate and the dimensions of the staff involvement shows the highest relationship, followed by top management commitment, continuous improvement and training and education, as shown in Table 5.

Table 5

Pearson Correlation Test for Each Dimension of TQM Practices and School Climate

\begin{tabular}{lc}
\hline \multicolumn{1}{c}{ Variable } & School Climate \\
\cline { 2 - 2 } & Correlation value $(\mathrm{r})$ \\
\hline The level of TQM practices & $0.63^{* *}$ \\
Customer Focus & $0.43^{* *}$ \\
Training and Education & $0.50^{* *}$ \\
Staff Involvement & $0.65^{* *}$ \\
Continous Improvement & $0.53^{* *}$ \\
\hline
\end{tabular}

$* * \mathrm{p}<0.01$ 
For the dimensions of school climate, the dimension of student relations has a strong relationship with TQM practices. It is followed by teaching innovation. Other dimensions show weak relationship, as shown in Table 6 below.

Table 6

Pearson Correlation Test for Each Dimension of School Climate and TQM Practices

\begin{tabular}{lc}
\hline \multicolumn{1}{c}{ Variable } & TQM practices \\
\cline { 2 - 2 } & Correlation value $(\mathrm{r})$ \\
\hline Collaboration & $0.40^{* *}$ \\
Student Relations & $0.58^{* *}$ \\
School Resources & $0.37 * *$ \\
Decision-Making & $0.34 * *$ \\
Teaching Innovation & $0.56^{* *}$ \\
\hline
\end{tabular}

$* * \mathrm{p}<0.01$

\section{TQM as a Predictor of School Climate}

In relation to TQM as a predictor of school climate, Table 7 shows that TQM practice is one of the factors that contributes to the school climate with contribution of 40 percent of the variance of changes in school climate $[\mathrm{F}(1,680)=453.60, \mathrm{p}<0.05]$. As a conclusion, TQM practice is a predictor of school climate with a standard regression coefficient $(\beta=.63, \mathrm{p}<0.05)$ significance.

\section{Table 7}

Regression Analysis Results of TQM Practices on School Climate

\begin{tabular}{lcccccc}
\hline Variable & B & Beta & R & R2 & Adj. R2 & t \\
\hline TQM practices & .45 & .63 & .63 & .40 & .40 & $21.30^{* * *}$ \\
\hline
\end{tabular}

Standard error: 0.39 . TQM practices contribute a total of $40.0 \%$ to the variance of the school climate

$* * \mathrm{p}<0.01$

For the dimensions of TQM practices, the results of data analysis show that significantly, only three (3) out of five (5) predictor variables, that are staff involvement $(\beta=.43, \mathrm{p}<0.05)$, top management 
commitment $(\beta=.21, \mathrm{p}<0.05)$ and continuous improvement $(\beta=.13, \mathrm{p}<0.05)$ are included in the regression model at $\mathrm{p}<0.05$. This means that only three (3) of these predictor variables are the factors of school climate $[\mathrm{F}(3,678)=197.09, \mathrm{p}<0.05]$. Therefore, training and education and customer focus are non-factor predictors of school climate. Table 9 shows the regression analysis of results obtained.

Table 8

Regression Analysis Results for the Dimensions of TQM on School Climate

\begin{tabular}{lrrrrrr}
\hline Variable & B & $\begin{array}{r}\text { Beta } \\
\text { Beta }\end{array}$ & R & R2 & Adj.R2 & \multicolumn{1}{c}{ t } \\
\hline Staff Involvement & .29 & .43 & .68 & .47 & .47 & $10.27^{* *}$ \\
Top Management Commitment & .14 & .21 & .68 & .47 & .47 & $5.05^{* *}$ \\
Continuous Improvement & .08 & .13 & .68 & .47 & .47 & $3.48^{* *}$ \\
Constant & 1.86 & & & & & $18.40^{* *}$ \\
\hline
\end{tabular}

The standard error of: 0.37 . All three of these dimensions contribute a total of $46.0 \%$ to the variance of the school climate

$* * \mathrm{p}<0.01$

For the dimensions of school climate on TQM practices, the results of data analysis show that significantly only four (4) of five (5) predictor variables, namely student relations $(\beta=.36, \mathrm{p}<0.05)$, teaching innovation $(\beta=.28, \mathrm{p}<0.05)$, decision-making $(\beta=.13$, $\mathrm{p}<0.05)$ and school resources $(\beta=.09, \mathrm{p}<0.05)$ are included in the regression model at $p<0.05$. It means that only four (4) of these predictor variables are factors of TQM practices $[F(4,677)$ $=132.01, \mathrm{p}<0.05]$, while collaboration is a non-factor predictor of TQM practices. Table 9 shows the regression analysis results attained.

Table 9

Regression Analysis Results for the Dimension of School Climate on TQM

\begin{tabular}{lcccccc}
\hline Variable & B & Beta & R & R2 & Adj.R2 & t \\
\hline Student Relations & .31 & .36 & .66 & .44 & .44 & $10.35^{* *}$ \\
Teaching Innovation & .29 & .28 & .66 & .44 & .44 & $7.48^{* *}$ \\
\hline \multicolumn{2}{r}{} & & & & \multicolumn{3}{c}{ (continued) }
\end{tabular}




\begin{tabular}{lcccccc}
\hline Variable & B & Beta & R & R2 & Adj.R2 & t \\
\hline Decision Making & .17 & .13 & .66 & .44 & .44 & $4.08 * *$ \\
School Resources & .08 & .09 & & & & $2.55 * *$ \\
Constant & 0.72 & & & & & $3.97 * *$ \\
\hline
\end{tabular}

The standard error of: 0.54 . These four dimensions contribute a total of $44.0 \%$ to the variance of TQM practices

$* * \mathrm{p}<0.01$

Generally, the levels of TQM practices are different in these three categories of schools. HPS show the highest level of TQM practices compared to average and low performance schools. Similar results are obtained for the level of school climate whereby the HPS scored the highest, followed by average and low performance schools. ANOVA analysis shows that there are significant differences for the level of TQM practices and the level of school climate in the three categories of schools. Analysis of the relationship between TQM practices with the school climate shows that there is a positive relationship of moderate strength between these two variables. Stepwise Regression Analysis was used in order to find out whether TQM is a predictor of school climate and the result indicates that TQM is a factor of school climate. The study shows that staff involvement, top management commitment and continuous improvement are dimensions of TQM that could become predictors of school climate.

Top management commitment is the most important factor which contributes to the success of TQM practices in an organization. The results are in line with the findings by Ahire et al. (1999) which found that top management commitment is an important factor in the implementation of TQM. This coincides with the Leadership Change Theory by Fullan (2002) which states that changes can occur if it is wanted by the leader. This clearly shows that the success of quality implementation in an organization depends on the commitment of top management. Quality improvement, through TQM, requires extensive changes that include policies, philosophies, structures and procedures. These changes can only occur if there is support from management because top managers are the policy-makers. The findings of this study support the theory that when the system is managed by the top management which is committed to quality, then the leader will build the vision and mission and support its 
implementation, both in terms of providing materials and equipment as well as support for the enthusiasm of subordinates (Goetsch \& Davis, 2003).

Values related to the three core principles of staff involvement, teamwork and continuous improvement are suggested to be imperative for leaders to successfully lead organizations through total quality transformations. According to Prajogo \& Sohal (2002), implicit in the TQM philosophy, are values of teamwork and collaboration in the pursuit of quality and continuous improvement. It appears evident that working with supportive co-workers who readily share task-relevant information and expertise is more likely to be associated with successful TQM implementation. In other words, for firms implementing TQM practices, higher co-worker support is likely to be associated with enhanced organizational performance. This study also supports the TQM perspective, which suggests that the involvement and participation of managers and employees at all levels is important for the continuous improvement and successful management of quality in organizations. In this study, it is also found that positive school climate has a significant correlation with the success of a school, as suggested by Lindahl (2009). Thus, organizations must build an open positive climate for enhancing organizational effectiveness.

\section{CONCLUSION}

The findings of the present study show that TQM has positive impact on school climate as well as school quality. However the level of practices in all the three categories of high, average and low performing schools is different. The findings of this study strengthen the theory of TQM in education by highlighting an excellent school model that links the main dimensions of the two variables, TQM practices and school climate, as shown in Figure 2.

In conclusion, the findings of this study provide a guide to the top management of the schools to reinforce the programs and training courses for the purpose of ensuring effective implementation of TQM in their schools. However, this study is limited to high, average and low performance schools in Kelantan. For this reason, it is 
recommended that in the future, a more comprehensive study should be conducted throughout Malaysia to ensure better generalizability. Future research also should explore the influence of principals' leadership styles because this factor may have an influence on TQM practices in schools.

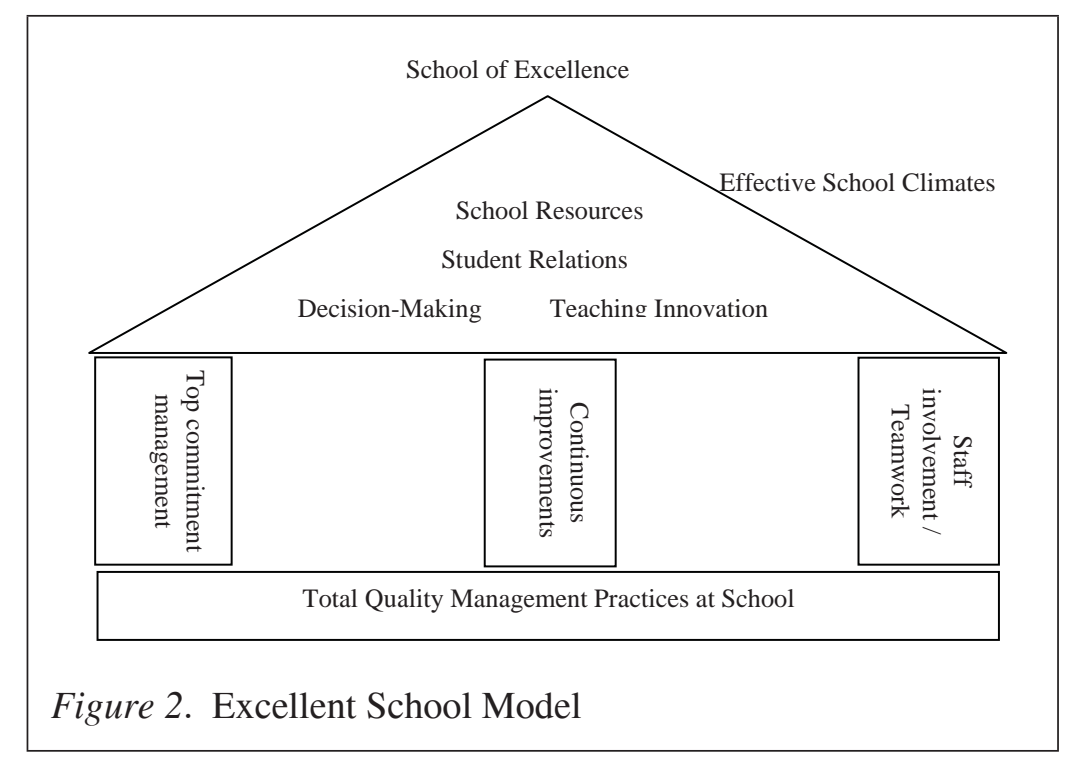

\section{REFERENCES}

Ahire, S. L., Golhar, D. Y., \& Waller, M. A. (1996). Development and validation of TQM implementation constructs. Decision Sciences, 27, 23-56.

Anderson, M., \& Sohal, A. S. (1999). A study of the relationship between quality management practices and performance in small businesses. International Journal of Quality \& Reliability Management, 9, 859-877.

Brigham, S. E. (1993). Lessons we can learn from industry. Change, $25(3), 42-47$.

Carter, S. C. (2000). No excuses: Lessons from high-performing, high-poverty schools. Washington, DC: The Heritage Foundation.

Creswell, J. W. (2008). Education Research: Planning, conducting, and evaluating quantitative and qualitative research (3rd ed.). New York: Pearson International Edition. 
Daft, R. L., \& Becker, S. W (1997). The innovative organization. New York: Elsevier.

Goetsch, D. L., \& Davis, S. B. (2003). Quality management: Introduction to total quality management for production, processing and services. New Jersey: Prentice Hall.

Hoy, W. K, \& Miskel, C. G., (1991). Educational administration: Theory, research and practice. New York: McGraw-Hill.

Johnson, B., Stevens, J. J., \& Zvoch, K. (2007). Teachers' perceptions of school climate. A validity study of scores from the revised school level environment questionnaire. Educational \& Psychological Measurement, 67(5), 833 - 844.

Keng Boon Ooi, Nooh Abu Bakar \& Veeri Arumugam. (2007). Does TQM influence employees' job satisfaction? An empirical case analysis. International Journal of Quality \& Reliability Management, 24(1), 62-77.

Koch, J. V., \& Fisher, J. L., (1998). Higher education and total quality management. Total Quality Management, 9( 8), 659668.

Kumar, M. R., \& Sankaran, S. (2007). Indian culture and the culture for TQM: A comparison. The TQM Magazine, 19(2), 176-188.

Kunnanatt, J. T. (2007). Impact of ISO 9000 on organizational climate. International Journal of Manpower, 28(2), 175-192.

Lam, M. Y., Gary, K. K., \& Chin, K. S. (2008). An organizational learning model for vocational education in the context of TQM culture. International Journal of Quality \& Reliability Management, 25(3), 238 - 255.

Lezotte, L. (2001). Revolutionary and evolutionary: The effective schools movement. Okemos, MI: Effective Schools Products.

Lim Kong Teong. (2003). Impak prinsip-prinsip TQM ke atas kepuasan hati pelajar dan pencapaian akademik pelajar: Satu kajian empirikal dalam sektor pendidikan tinggi awam di Malaysia. Unpublished (doctoral dissertation). Universiti Utara Malaysia.

Lim Kong Teong \& Tang Swee Mei. (2001). Amalan pengurusan kualiti menyeluruh dalam proses pengajaran dan pembelajaran. Sekolah Pengurusan, Universiti Utara Malaysia. Lindahl, R. (2009). School climate differences between highperforming and low-performing schools that serve highpoverty populations. International Journal of Educational Leadership Preparation, 10(1), 1-16. 
Marshall, J. C., Pritchard, R. J., \& Gunderson, B. (2004). Cultural norming in schools in 'healthy' and 'unhealthy' districts. Leadership \& Policy in Schools, 3(2), 85-109.

Mohamad Muda. (2002). Cabaran pendidikan masa kini. Retrieved from http.//www.scribd.com

National Education Blueprint. (2008). Retrieved from http: www. moe.edu.my

Ngware M. W., Wamukuru, D. K., \& Odebero, S. O. (2006). Total quality management in secondary schools in Kenya: Extent of Practice. Quality Assurance In Education, 14(4), 339-362.

Noorliza Karia. \& Muhammad Hasmi Hassan Asaari. (2006). The effects of TQM practices on employees' work-related attitudes. The TQM Magazine, 18(1), 30-43.

PADC. (1992). Public Administration Development Circular. No 1/1992. Guide to Total Quality Management (TQM) for Public Service.

Pashiardis, G. (2000). School climate in elementary and secondary schools: View of cypriot principals and teachers. The International Journal of Educational Management, 14(5).

Paul, C. L. (1998). The relationship between the principles of TQM and school climate, school culture and teacher empowerment. Unpublished (doctoral dissertation). University of Missouri, Columbia.

Peat, M., Taylor, C. E., \& Franklin, S. (2005). Re-engineering of undergraduate science curricula to emphasise development of lifelong learning skills. Innovations in Education and Teaching International, 42(2), 135-146.

Prabhu, V., Alex, A., Yarrow, D., \& Mitchell, E. (2000). The impact of ISO 9000 and TQM on best practice / performance. The TQM Magazine, 12(2), 84 - 91.

Prajogo, D. I., \& Mc Dermott, C. M. (2005). The relationship between TQM practices and organizational culture. International Journal of Operations \& Production Management, 25(11), 1101-1122.

Prajogo, D. I., \& Sohal, A. S. (2002). The relationship between TQM practices, quality performance and innovation performance. TQM practices quality and innovation. International Journal of Quality \& Rehability Management, 20(8), 901-918.

Sitalakshmi, V. (2007). A framework for implementing TQM in higher education programs. Quality Assurance in Education, 15(1), 92-112. 
Srikanthan, G., \& Dalrymple, J. (2004). A synthesis of a quality management model for education in universities. The International Journal of Educational Management, 18(4), 266-279.

Susan, W. E. (1995). Total quality: A mechanism for institutional change and curriculum reform. Academic Initiatives in Total Quality for Higher Education, ASQC, Quality Press, Milwaukee, WI, 135-158.

Tan, K. C., Wong, M. F., Mehta, T., \& Khoo, H. H. (2003). Factors affecting the development of national quality awards. Measuring Business Excellence, 7(3), 37-45.

Telford, R., \& Masson, R. (2005). The congruence of quality values in higher education. Quality Assurance in Education, 13 (2), 107-119.

Toremen, F., \& Karakus, M. (2009). Total quality management practices in Turkish primary schools. Quality Assurance in Education, 17(1), 30-44.

Zhang, Z. H., Waszine, A., \& Wijngaard, J. (2000). An instrument for measuring TQM implementation for Chinese manufacturing companies. International Journal of Quality \& Reliability Management, 17(7), 730-755. 